\title{
GAYA BAHASA DAKWAH DI DAERAH PESISIR
}

\author{
Nurmy A.R
}

\begin{abstract}
ABSTRAK
Islam adalah agama dakwah yakni agama yang mengajak pada kebaikan dan mencegah pada kemungkaran pada seluruh umat Islam dimanapun ia berada, tak terkecuali bagi umat Islam yang berada di daerah pesisir. Hal ini dikarenakan dakwah merupakan usaha peningkatan pemahaman keagamaan untuk mengubah pandangan hidup, sikap batin, dan prilaku ummat yang tidak sesuai dengan ajaran Agama Islam menjadi sesuai dengan tuntunan syariat Islam untuk memperoleh kebahagiaan dunia dan akhirat. Banyak cara yang dilakukan oleh para penceramah untuk dapat memasuki ritme ataupun tipe jama'ahnya, termasuk dengan memilih gaya bahasa yang sesuai dengan latar belakang sosial, ekonomi, pendidikan, maupun geografisnya. Khususnya keadaan geografis jama'ah, terkadang menjadi tantangan bagi para alim ulama dalam memilih gaya berdakwah maupun gaya bahasa mereka dalam berdakwah agar mereka dapat diterima dengan baik.
\end{abstract}

Kata Kunci: geografi, latar belakang, da`i

\section{A. Pendahuluan}

Dakwah adalah sebuah ungkapan yang digunakan oleh ummat muslim Indonesia yang diambil dari kata bahasa Arab da'wah yang berkonotasi sebuah kegiatan menyampaiakan, menyiarkan, menyebarkan, mengingatkan, dan mengajarkan ajaran Islam kepada ummat muslim maupun non-muslim. Sebagai seorang muslim, merupakan kewajiban untuk saling mengingatkan akan kebaikan, kabar gembira, maupun azab kepada sesama muslim. Hal ini merupakan suatu kewajiban yang tidak tertulis dan melekat pada setiap individu muslim.

Berdakwah sebagai sebuah paket keindahan dan kelebihan seorang alim muslim atau yang dikenal dengan sebutan ustadz/ustadzah, Pak Haji, penceramah, dsb. merupakan salah satu kegiatan yang harus selalu bersinergi dengan perkembangan zaman dan situasi yang berlaku di tempat ia berdakwah, karena berdakwah di kalangan cendikia, anak muda, ataupun orang tua pasti akan berbeda, begitu 
pula dengan tempat dakwahnya, berdakwah di daerah dengan penduduk mayoritas pekerja kasar, pekerja serabutan, pekerja kantoran, juga akan berbeda, pun daerah-daerah dengan keadaan geografis tertentu. Gaya bahasa berdasrkan variasi geografis jamaah inilah yang penulis berusaha angkat dalam tulisan ini.

\section{B. Gaya Bahasa \\ 1. Pengertian}

Gaya bahasa menurut Aminuddin (1995: 5) adalah cara yang digunakan oleh pengarang dalam memaparkan gagasannya sesuai dengan tujuan dan efek yang ingin dicapai. Menurut Tarigan (1985: 5) gaya bahasa merupakan bentuk retorik, yaitu penggunaan katakata dalam berbicara dan menulis untuk meyakinkan atau mempengaruhi penyimak dan pembaca. Harimurti dalam Pradopo (Pradopo, 1993: 265) mengungkapkan definisi gaya bahasa sebagai pemanfaatan atas kekayaan bahasa seseorang dalam bertutur atau menulis, lebih khusus adalah pemakaian ragam bahasa tertentu untuk memperoleh efek tertentu. Efek yang dimaksud dalam hal ini adalah efek estetis yang menghasilkan nilai seni.

Definisi gaya bahasa dituturkan pula oleh Achmadi (1988: 155-156), yang menyatakan bahwa gaya bahasa adalah kualitas visi, pandangan seseorang, karena merefleksikan cara seorang pengarang memilih dan meletakkan kata-kata dan kalimatkalimat dalam mekanik karangannya. Gaya bahasa menciptakan keadaan perasaan hati tertentu, misalnya kesan baik ataupun buruk, senang, tidak enak dan sebagainya yang diterima pikiran dan perasaan karena pelukisan tempat, benda-benda, suatu keadaan atau kondosi tertentu. Dalam bukunya, Albertine (2005: 51) mengemukakan, gaya bahasa adalah bahasa yang bermula dari bahasa yang biasa digunakan dalam gaya tradisional dan literal untuk menjelaskan orang atau objek. Dengan menggunakan gaya bahasa, pemaparan imajinatif menjadi lebih segar dan berkesan. Gaya bahasa mencakup: arti kata, citra, perumpamaan, serta simbol dan alegori. Arti kata mencakup, antara lain: arti denotatif dan konotatif, alusi, parody dan sebagainya; sedangkan perumpamaan mencakup, antara lain: simile, metafora dan personifikasi.

Luxemburg dkk (1990: 105) mengungkapkan bahwa gaya bahasa merupakan sesuatu yang memberikan ciri khas pada sebuah teks. Teks pada giliran tertentu dapat berdiri semacam individu yang berbeda dengan individu yang lain. Gaya bahasa yang baik itu harus mengandung tiga unsur yaitu kejujuran, sopan santun dan menarik. 
Dikatakannya bahwa dalam hal gaya ini kita mengenal dua istilah yaitu "bahasa retorik" (rhetorical device) dan "bahasa kias" (figure of speech). Bahasa retorik atau gaya bahasa dan bahasa kias merupakan penyimpangan dari bahasa (Keraf 1981: 115).

Gaya atau khususnya gaya bahasa dikenal dalam istilah retorika dengan istilah style. Kata style diturunkan dari kata latin stilus, yaitu semacam alat untuk menulis pada lempengan lilin, keahlian menggunakan alat ini akan mempengaruhi jelas tidaknya tulisan pada lempengan tadi. Kelak pada waktu penekanan dititik beratkan pada keahlian untuk menulis indah, maka style lalu berubah menjadi kemampuan dan keahlian untuk menulis atau menggunakan kata-kata secara indah.

Gaya adalah ciri khas penceramah ketika menyampaikan sesuatu pesan kepada para pendengar (audien), biasanya gaya (style) penceramah relatif tetap. Oleh karena itu ceramah yang baik, gaya perlu mendapatkan perhatian yang serius. Jadi gaya yang sudah menjadikan ciri khas itu dapat diperbaiki dan diperbanyak agar dapat bervariasi. Ini dimaksud untuk menjauhkan kebosanan dan dugaan yang kurang baik dari para audien.

Walaupun kata style berasal dari bahasa latin, orang yunani sudah mengembangkan sendiri teori-teori mengenai style itu. Ada dua aliran yang terkenal, yaitu:

1. Aliran Platonik: menganggap style sebagai kualitas suatu ungkapan, menurut mereka ada ungkapan yang memiliki style, ada juga yang tidak memiliki style.

2. Aliran Aristoteles: menganggap bahwa gaya adalah suatu kualitas yang inheren, yang ada dalam tiap ungkapan.

Dengan demikian, aliran Plato mengatakan bahwa ada karya yang memiliki gaya dan karya yang sama sekali tidak memiliki gaya. Sebaliknya, Aliran Aristoteles mengatakan bahwa semua karya memiliki gaya, tetapi ada karya yang memiliki gaya yang tinggi ada yang rendah, ada karya yang memiliki gaya yang kuat, ada yang lemah, ada yang memiliki gaya yang baik dan juga ada yang memiliki gaya yang jelek.

Dilihat dari segi bahasa, gaya bahasa adalah cara menggunakan bahasa. Gaya bahasa memungkinkan kita dapat menilai pribadi, watak, dan kemampuan seseorang yang mempergunakan bahasa itu. Semakin baik gaya bahasanya, semakin baik pula penilaian orang terhadapnya; semakin buruk gaya bahasa seseorang, semakin buruk pula penilaian yang diberikan padanya. 
Syarat-syarat gaya bahasa yang baik harus mengandung tiga unsur, yaitu:

1. Kejujuran

Kejujuran adalah suatu pengorbanan. Bila orang hanya mencari kesenangan dengan mengabaikan segi kejujuran, maka akan timbullah hal-hal yang menjijikkan. Hidup seseorang (manusia) hanya dapat bermanfaat bagi dirinya sendiri dan bagi sesamanya, kalau hidup itu dilandaskan pada sendisendi kejujuran.

2. Sopan santun

Yang dimaksud sopan santun adalah memberi penghargaan atau menghormati orang yang diajak bicara, khususnya pendengar atau pembaca.

\section{Menarik}

Gaya bahasa yang digunakan oleh da'i harus menarik. Sebuah gaya yang menarik dapat diukur melalui beberapa komponen berikut. Variasi, humor yang sehat, pengertian yang baik, tenaga hidup (vitalitas), dan penuh gaya hayal (imajinasi). Bila kita melihat gaya secara umum, kita dapat mengatakan bahwa gaya adalah cara mengungkapkan diri sendiri, entah melalui bahasa, tingkah laku, berpakaian, dan sebagainya.

Sedangakan dalam bukunya Asmuni syukir "dasar-dasar Strategi Dakwah Islam", disebutkan bahwa Gaya (style) ini meliputi gerak tangan, gerak anggota tubuh, mengerutkan kening, arah pandang, melihat persiapan, membuka lembaran buku persiapan dan sebagainya. Gaya dianggap penting, untuk menunjang keberhasilan dalam menyampaikan pesan. Sebagaimana dikatakan oleh Ernest G. Bormann dan Nancy C. Bormann bahwa : "Seorang pembicara bisa memberikan tekanan lebih atau memperluas kata-kata suatu pesan secara non verbal. Teknik ini dapat meningkatkan sifat ekspresi pembicara dan semakin memperjelas informasi. Penyampai pesan dapat mengulang makna (memperbanyak) dengan mengatakan hal-hal yang sama secara non verbal dan verbal, sehingga gerak tubuh, melodi vocal, dan kata-kata, saling memperkuat.

Gerak tubuh juga membantu menguatkan bunyi vocal, memberi kerangka, atau menguatkan ucapan bagi seorang pembicara. Pembicara dapat menggunakan anggukan kepala, gerak lengan, atau gerak jarinya untuk menunjukkan bilamana komentar mulai dan berakhir.

Salah satu alat terpenting yang digunkan pembicara dalam komunikasi non verbal yaitu ekpresi wajah. Senyum, ketawa, kerutan dahi, mimik yang lucu, gerakan alis yang menujukkan keraguan, rasa kaget dan sebainya dapat menekankan atau mengungkapkan maksud pembicara. Namun kenyataan 
menunjukkan bahwa banyak pembicara yang gagal untuk menggunakan ekspresi wajah sebagai alat komunikasi yang efektif.

Sebagai akibatnya, pembicara hanya akan menghasilkan pembicaraan yang monoton dan membosankan serta menunjukkan ekspresi wajah yang kosong. Begitu juga seseorang yang berbicara di depan publik, seringkali kelihatan menjenuhkan. Hal ini disebabkan karena ia tidak sadar bahwa ekspresi wajahnya tidak dapat ditangkap oleh hadirin yang jauh dari tempat ia berbicara. Senyuman sering tidak dapat dilihat dalam jarak dua belas kaki atau lebih.

\section{Jenis-Jenis Gaya Bahasa \\ a. Segi Non bahasa}

Pengikut Aristoteles menerima style sebagai hasil dan bermacammacam unsur. Pada dasarnya style dapat dibagi atas tujuh pokok sebagai berikut:

1. Berdasarkan pengarang: Gaya yang disebut sesuai dengan nama pengarang dikenal berdasarkan ciri pengenal yang digunakan pengarang atau penulis dalam karangannya.

2. Berdasarkan Masa: Gaya bahasa yang didasarkan pada masa dikenal karena ciri-ciri tertentu yang berlangsung dalam suatu kurun waktu tertentu. Misalnya ada gaya lama, gaya klasik, gaya sastra modern, dan sebagainya.

3. Berdasarkan Medium: yang dimaksud dengan medium adalah bahasa dalam arti alat komunikasi. Tiap bahasa, karena struktur dan situasi sosial pemakainya, dapat memiliki corak tersendiri.

4. Berdasarkan Subyek: Subyek yang menjadi pokok pembicaraan dalam sebuah karangan dapat mempengaruhi pula gaya bahasa sebuah karangan.

5. Berdasarkan Tempat: Gaya ini mendapat namanya dari lokasi geografis, karena ciri-ciri kedaerahan mempengaruhi ungkapan atau ekspresi bahasanya. Ada gaya Jakarta, gaya Jogya, ada gaya Medan, Ujung Pandang, dan sebagainya.

6. Berdasarkan Hadirin: seperti halnya dengan subyek, maka hadirin atau jenis pembaca juga mempengaruhi gaya yang dipergunakan seorang pengarang. Ada gaya populer atau gaya demagog yang cocok untuk rakyat banyak. Ada gaya sopan yang cocok untuk lingkungan istana atau lingkungan yang terhormat. Ada pula gaya intim (familiar) yang cocok untuk lingkungan keluarga atau untuk orang yang akrab.

7. Berdasarkan Tujuan: gaya berdasarkan tujuan memperoleh 
namanya dan maksud yang ingin disampaikan oleh pengarang. di mana pengarang ingin mencurahkan gejolak emotifnya.

\section{b. Segi Bahasa}

Dilihat dan sudut bahasa atau unsur-unsur bahasa yang digunakan maka gaya bahasa dapat dibedakan berdasarkan titik tolak unsur bahasa yang dipergunakan, yaitu:

1. Gaya bahasa berdasarkan pilihan kata

2. Gaya bahasa berdasarkan nada yang terkandung dalarn wacana

3. Gaya bahasa berdasarkan struktur kalimat

4. Gaya bahasa berdasarkan langsung tidaknya makna.

\section{c. Gaya Bahasa berdasarkan Pilihan Kata}

Dalam bahasa standar (bahasa baku) dapatlah dibedakan: gaya bahasa resmi (bukan bahasa resmi), gaya bahasa tak resmi dan gaya bahasa percakapan.

\section{1). Gaya Bahasa Resmi}

Gaya bahasa resmi adalah gaya dalam bentuknya yang lengkap, gaya yang dipergunakan dalam kesempatan-kesempatan resmi, gaya yang dipergunakan oleh mereka yang diharapkan mempergunakannya dengan baik dan terpelihara. Amanat kepresidenan, berita negara, khutbahkhutbah mimbar, tajuk rencana, pidato-pidato yang penting, artikelartikel yang serius atau esei yang memuat subyek-subyek yang penting, semuanya dibawakan dengan gaya bahasa resmi.

\section{2). Gaya Bahasa Tak Resmi}

Gaya bahasa tak resmi juga merupakãn gaya bahasa yang dipergunakan dalam bahasa standar, khususnya dalam kesempatakesempatan yang tidak formal atau kurang formal. Bentuknya tidak terlalu konservatif. Gaya ini biasanya dipergunakan dalam karya-karya tulis, buku-buku pegangan, artikel-artikel mingguan atau bulanan yang baik, dalam perkuliahan, editorial, kolumnis, dan sehagainya. Singkatnya gaya bahasa tak resmi adalah gaya bahasa yang umum dan normal bagi kaum terpelajar.

\section{3). Gaya Bahasa Percakapan}

Sejalan dengan kata-kata percakapan, terdapat juga gaya bahasa percakapan. Dalam gaya bahasa ini, pilihan katanya adalah kata-kata populer dan kata-kata percakapan. Namun di sini harus ditambahkan segi-segi morfologis dan sintaksis, yang secara bersama-sama membentuk gaya bahasa percakapan ini. Biasanya segi-segi sintaksis tidak terlalu diperhatikan, demikian pula 
segi-segi morfologis yang biasa diabaikan sering dihilangkan. Kalau dibandingkan dengan gaya bahasa resmi dan gaya bahasa tidak resmi, maka gaya bahasa percakapan ini dapat diumpamakan sebagai bahasa dalam pakaian sport. Itu berarti bahasanya masih lengkap untuk suatu kesempatan, dan masih dibentuk menurut kebiasaankebiasaan, tetapi kebiasaan ini agak longgar bila dibandingkan dengan kebiasaan pada gaya bahasa resmi dan tidak resmi.

\section{d. Gaya Bahasa Berdasarkan Nada}

Gaya bahasa berdasarkan nada didasarkan pada sugesti yang dipancarkan dan rangkaian kata-kata yang terdapat dalam sebuah wacana. Sering kali sugesti ini akan lebih nyata kalau diikuti dengan sugesti suara dan pembicara, bila sajian yang dihadapi adalah bahasa lisan.

\section{a). Gaya Sederhana}

Gaya ini biasanya cocok digunakan untuk memberikan instruksi, perintah, pelajaran, perkuliahan, dan sejenisnya.

\section{b). Gaya Mulia dan Bertenaga}

Sesuai dengan namanya, gaya ini penuh dengan vitalitas yang biasanya dipergunakan untuk menggerakkan sesuatu.
Menggerakkan sesuatu tidak saja dengan mempergunakan tenaga dan vitalitas pembicara, tetapi juga dapat mempergunakan nada keagungan dan kemuliaan. Tampaknya hal ini mengandung kontradiksi, tetapi kenyataannya memang demikian. Nada yang agung dan mulia akan sanggup pula menggerakkan emosi setiap pendengar.

Dalam keagungan, terselubung sebuah tenaga yang halus tetapi secara aktif ia meyakinkan bekerja untuk mencapai suatu tujuan tertentu. Khotbah tentang kemanusiaan dan keagamaan, kesusilaan dan ketuhanan biasanya disampaikan dengan nada yang agung dan mulia. Tetapi di balik keagungan dan kemuliaan itu terdapat tenaga penggerak yang luar biasa, tenaga yang benar-benar mampu menggetarkan emosi para pendengar atau pembaca.

\section{c). Gaya Menengah}

Gaya menengah adalah gaya yang diarahkan kepada usaha untuk menimbulkan suasana senang dan damai. Karena tujuannya adalah menciptakan suasana senang dan damai, maka nadanya juga bersifat lemah-lembut, penuh kasih sayang, dan mengandung humor yang sehat.

Pada

kesempatankesempatan khusus seperti pesta, 
pertemuan, dan rekreasi, orang lebih menginginkan ketenangan dan kedamaian. Akan ganjillah rasanya, atau akan timbul disharmoni, kalau dalam suatu pesta pernikahan ada orang yang memberi sambutan berapi-api, mengerahkan segala emosi dan tenaga untuk menyampaikan sepatah kata. Para hadirin yang kurang waspada akan turut terombang-ambing dalam permainan emosi semacam itu.

\section{e. Gaya Bahasa berdasarkan Struktur Kalimat}

Berdasarkan struktur kalimat sebagaimana yang dikemukakan di atas, maka dapat diperoleh gaya-gaya bahasa sebagai berikut:

\section{a. Klimaks}

Gaya bahasa klimaks diturunkan dan kalimat yang bersifat periodik. Klimaks adalah semacam gaya bahasa yang mengandung urutan-urutan pikiran yang setiap kali semakin meningkat kepentingannya dan gagasan-gagasan sebelumnya.

Klimaks disebut juga gradasi. Istilah ini dipakai sebagai istilah umum yang sebenamya merujuk kepada tingkat atau gagasan tertinggi. Bila klimaks itu terbentuk dan beberapa gagasan yang berturut-turut semakin tinggi kepentingannya, maka ia disebut anabasis.

\section{b. Antiklimaks}

Antiklimaks dihasilkan oleh kalimat yang berstruktur mengendur. Antiklimaks sebagai gaya bahasa merupakan suatu acuan yang gagasan-gagasannya diurutkan dan yang terpenting berturut-turut ke gagasan yang kurang penting. Antiklimaks sering kurang efektif karena gagasan yang penting ditempatkan pada awal kalimat, sehingga pembaca atau pendengar tidak lagi memberi perhatian pada bagian-bagian berikutnya dalam kalimat itu.

\section{c. Paralelisme}

Paralelisme adalah semacam gaya bahasa yang berusaha mencapai kesejajaran dalam pemakaian kata-kata atau frasa-frasa yang menduduki fungsi yang sama dalam bentuk gramatikal yang sama. Kesejajaran tersebut dapat pula berbentuk anak kalimat yang bergantung pada sebuah induk kalimat yang sama. Gaya ini lahir dan struktur kalimat yang berimbang.

\section{d. Antitesis}

Antitesis adalah sebuah gaya bahasa yang mengandung gagasangagasan yang bertentangan, dengan mempergunakan kata-kata atau kelompok kata yang berlawanan. Gaya ini timbul dan kalimat berimbang. 


\section{e. Repetisi}

Repetisi adalah perulangan bunyi, suku kata, kata atau bagian kalimat yang dianggap penting untuk memberi tekanan dalam sebuah konteks yang sesuai. Dalam bagian ini hanya akan dibicarakan repetisi yang berbentuk kata atau frasa atau klausa. Karena nilainya dianggap tinggi, maka dalam oratori timbullah bermacam-macam variasi repetisi.

\section{Gaya Irama Suara}

Merupakan seni dalam berkomunikasi, untuk memikat perhatian dapat dikerjakan dengan jalan berbicara dengan irama yang berubah-ubah sambil disana-sini memberikan tekanan-tekanan tertentu pada kata-kata yang memerlukan perhatian khusus.

Undersch dan Staats dalam bukunya (1951), menyebutkan ada 4 variabel yang perlu diperhatikan mengenai suara, yaitu :

a. Pitch

Dalam pengertian musik, pitch disebut dengan tangga nada. Biasanya ada suara pembicara yang terlalu tinggi atau terlalu rendah. Seharusnya suara yang dikeluarkan bervariasi (rendah, sedang dan tinggi), sesuai dengan penghayatan terhadap materi pembicaraan.

b. Quality
Quality ialah mutu, watak, sifat atau tabiat dari suara. Dalam dunia musik biasanya disebut Timbre. Dalam berbicara, timbre suara ini, ikut menentukan enak tidaknya suara kita didengar andience. Timbre suara harus disesuaikan dengan materi yang disampaikan termasuk faktor lain yang berkaitan dengan pengucapan kalimat dan kata-kata.

\section{c. Loudness}

Loudness menyangkut keras atau tidaknya suara. Dalam berceramah, ini perlu menjadi perhatian. Kita harus mampu mengatur atau lunaknya suara yang kita keluarkan, dan ini tergantung pada situasi dan kondisi yang kita hadapi.

\section{d. Rate dan Rhythm}

Yaitu cepat, lambat dan irama suara. Biasanya cepat atau lambatnya suara berhubungan erat dengan rhythm dan irama. Para pembicara mesti memperhatikan masalah ini dengan serius. Kita harus mengatur kecepatan suara dan serasikan suara dengan irama. Suara yang disampaikan terlalu cepat atau terlalu lambat, akan menyulitkan pendengar dalam menangkap maksud pembicaraan bahkan pendengar menjadi dingin dan lesu.

\section{Gaya Gerak-Gerik Tubuh}


Ada beberapa hal berkaitan dengan gaya gerak-gerik tubuh, yakni:

a. Sikap Badan (cara berdiri)

Sikap badan selama berbicara (terutama pada awal pembicaraan) baik duduk atau berdiri menentukan berhasil atau tidaknya penampilan kita sebagai pembicara. Sikap badan (cara berdiri) dapat menimbulkan berbagai penafsiran dari pendengar yang menggambarkan gejala-gejala penampilan kita.

\section{b. Penampilan dan Pakaian}

Pentingnya beberapa gerak penyerta (body action). Gerak penyerta ialah sesuatu keadaan yang mengikuti atau terjadi pada waktu kita mengumpulkan sesuatu. Biasanya gerak penyerta ini bukan sesuatu yang di buatbuat, tetapi timbul secara spontan dan wajar sesuai dengan keadaan hati dan emosi.

Disamping penampilan, masalah pakaian juga menjadi perhatian. Pakaian bagian dari diri kita, bila pakaian dinilai kurang pantas, berarti diri kita belum tampil didepan umum (mereka). Kata orang pakaian yang pantas, pasti akan menambah kewibawaan. Di dalam praktek, cukup banyak pembicara yang mengabaikan pakaian ini.

c. Air Muka (ekspresi) dan gerakan tangan

Penyajian materi mesti didukung dengan air muka (ekspresi wajah) yang wajar dan tepat. Dengan kata lain, materi yang dihayati harus tampak melalui air muka. Perlu diketahui, air muka (ekspresi) bukan sekedar seni untuk mengikat perhatian. Lebih jauh dari itu, warna air muka yang tepat akan menyentuh langsung jiwa dan pikiran pendengar.

Ekspresi wajah merupakan salah satu alat terpenting yang digunakan pembicara dalam berkomunikasi non verbal yang meliputi senyuman, ketawa, kerutan dahi, mimik yang lucu, gerakan alis yang menunjukkan keraguan, rasa kaget dan sebagainya.

Demikian pula pada gerakan tangan. Dalam berceramah atau pidato menggunakan gerakan tangan dalam menyajikan materi pasti menarik perhatian pendengar. Gerakan tangan yang sempurna mampu membuat gambar abstrak dari materi yang disampaikan, sehingga tertangkap dengan jelas oleh jiwa atau pikiran pendengar melalui mata. Walaupun demikian, perlu diingat, jangan salah melakukan gerakan tangan.Sebab bila salah justru yang terjadi adalah sebaliknya. Bahkan bisa menjadi bahan tertawa bagi peserta atau mad'u (mitra dakwah).

d. Pandangan Mata

Menggunakan pandangan mata, juga merupakan gaya untuk memikat perhatian peserta (komunikan). Kata orang, mata adalah matahari pada diri 
manusia. Mata tidak saja digunakan untuk melihat, untuk kontak dengan orang lain bahkan juga dapat digunakan sebagai alat atau cermin dari kepribadian orang. Artinya, diri kita bisa dinilai orang lain melaui sorotan mata yang kita pancarkan.

Selama berbicara didepan umum, pandangan mata sangatlah menentukan. Mata dapat mengeluarkan kakuatan magis yang cukup kuat, untuk mengarahkan dan mengendalikan perhatian peserta. Akhirnya matalah yang menentukan terjadinya atau tidaknya kontak antara pembicara dengan audience.

\section{Gaya Bahasa Dakwah Islam}

Gaya bahasa dakwah menurut Hasmy (1984: 262) merupakan suatu perkataan yang berupa tulisan dan lisan yang memberikan unsur-unsur memperingati, mempengaruhi, mengajak kepada kebaikan dan memiliki indikatorindikator seperti taklim dan tarbiyah (pengajaran dan pendidikan), tazkir dan tanbih (peringatan dan penyegaran kembali), targhib dan tabsyir (menggemarkan manusia pada amal shalih dengan menampilkan berita pahala), tarkib dan inzar (penakutan dengan mengemukakan berita siksa), qhasas dan riwayat (penampilan cerita masa lalu), amar dan nahi perintah dan larangan).

Dakwah menggunakan bahasa untuk menyampaikan pesan kepada objek dakwah (mad'u). Dalam bukunya, Qardhawi (1988: 4) menjelaskan ada tiga hal yang dibutuhkan dai dalam berdakwah yaitu: iman, akhlak dan ilmu pengetahuan. Salah satu ilmu pengetahuan yang harus dai kuasai adalah Ilmu Bahasa dan Kesusastraan. Ilmu Bahasa agar bisa berbahasa dengan baik dan benar, sedangkan IImu Kesusastraan agar bisa membuat ungkapan-ungkapan yang menarik. Hal ini merupakan kelengkapan taktis yang tujuannya agar tidak membuat mad'u salah paham terhadap ungkapanungkapan dai dan tidak segan mendengarkan atau membaca pesan dakwahnya.

Dakwah bisa dilakukan dengan beberapa metode yaitu da'wah bil lisan, da'wah bil qalam, dan da'wah bil hal. Penggunaan bahasa sangat penting dalam semua metode tersebut, namun kelebihan gaya bahasa atau da'wah bil lisan, kata yang terucap bisa langsung dijelaskan. Apanila terjadi kesalahpahaman, sang da'i bisa langsung mengkonfirmasinya (Chaer, 2012: 83-84).

Bahasa dakwah Islam bertujuan untuk memengaruhi dan mentransformasikan sikap batin dan 
perilaku warga masyarakat (pendengar) menuju suatu tatanan kesalehan individu dan kesalehan sosial. Dakwah dengan pesan-pesan keagamaan dan pesanpesan sosialnya juga merupakan ajakan kepada kesadaran untuk senantiasa memiliki komitmen (istiqomah) di jalan yang lurus (Munir, 2012:1). Aktivitas keagamaan yang secara langsung digunakan untuk mensosialisasikan ajaran Islam bagi penganutnya dan umat manusia pada umumnya adalah aktivitas dakwah.

Dalam aktivitas dakwah Islam, seorang penceramah atau biasa yang disebut ustadz dalam kegiatan dakwahnya banyak melakukan aktivitas dakwah lisan (dakwah bi al-lisan). Kegiatan dakwah itu bukan hanya mencakup sisi pelakunya (ustadz) juga pesertanya (jama'ah), ia juga mempunyai metode beragam yang telah digariskan dalam Al-Qur'an dan dipraktikkan oleh Rasulullah Saw (Haq, 2010:112). Di zaman sekarang di kalangan masyarakat, yang terlihat bahwa kegiatan dakwah yang dilakukan oleh para ustadz sudah mengandung unsur kekerasan dalam mengajak para jama'ahnya untuk berbuat kebaikan dengan cara paksaan. Padahal yang harus dilakukan oleh para ustadz yakni dengan cara yang dipraktikkan Rasulullah Saw yakni dengan cara lemah lembut, sopan santun dan menyenangkan guna untuk menarik perhatian para jama'ah.

Adapun jenis gaya bahasa dakwah yang dikemukakan Hasmy (1984: 266) dalam bukunya antara lain:

1. Taklim dan Tarbiyah

Yang dimaksud dengan taklim atau pengajaran, yaitu mengajar atau member pelajaran bersandar kepada al-Qur'an, al-Hadis, ilmu pengetahuan, dan hasil riset serta penelitian. Sedangkan tarbiyah atau biasa disebut dengan pendidikan, yaitu mendidik berdasarkan al-Qur'an, al-Hadis, dan ilmu pengetahuan agar manusia benar-benar akan tujuan hidup untuk menyembah AllahAllah dengan segala perintah-Nya dan menjauhi larangan-Nya. Dalam hal ini tugas taklim dan tarbiyah yaitu mengajar dan mendidik manusia agar benar-benar mempunyai aqidah yang shahih dan bermu'amalah dalam segala bidang dengan berpedoman akan ajaran-ajaran Islam dalam alQur'an dan Hadis.

\section{Tazkir dan Tanbih}

Tazkir dan Tanbih adalah mengingatkan dan menyadarkan kembali akan pengajaran dan pendidikan yang diterimanya.

\section{Targhib dan Tabsyir}


Tarqhib yakni gaya bahasa dakwah yang berisikan ajakan agar manusia gemar melakukan amal shaleh. Sedangkan gaya bahasa tabsyir adalah gaya bahasa dakwah yang menampilkan atau mengemukakan berita pahala. Kedua gaya bahasa ini digunakan untuk orang-orang yang telah beriman namun belum mau mengerjakan perintah-perintah Allah sesuai dengan ajaran Agama Islam.

\section{Tarhib dan Inzarini}

Tarhib adalah gaya bahasa dakwah yang berisi ancaman untuk menakutnakuti manusia yang suka melanggar larangan Allah SWT. sedangkan inzar adalah gaya bahasa dakwah yang menampilkan berita siksa bagi manusia yang taatpada perintah dan larangan Allah SWT.

\section{Qashash dan Riwayat}

Qashash dan riwayat adalah gaya bahasa dakwah yang menampilkan cerita-cerita masa lalu, baik cerita yang berakhir azab ataupun cerita yang berakhir kebahagiaan.

\section{Amar dan Nahi}

Gaya bahasa amar dan nahi adalah gaya bahasa yang berisi perintah dan larangan. Di setiap perintah tersebut diikuti oleh penampilan berita pahala bagi yang mengerjakannya. Begitu pula dengan larangan, di setiap larangan itu diikuti dengan ancaman dan berita bagi orang yang melanggarnya.

Dari keenam gaya bahasa dakwah di atas, dapat pula kita simpulkan bahwa dalam berdakwah, seorang da'i atau muballigh dapat menggabungkan dua ataupun lebih gaya bahasa tersebut. Namun, terlepas dari gaya bahasa lisan yang digunakan dalam berdakwah ternyata kemampuan penceramah dalam mengundang perhatian jama'ah sangatlah penting, baik dengan menggunakan mimik, nada suara yang sesuai, dan personal style (dengan memperhatikan background dan tipe jamah) yang dapat dijadikan ciri khas pemikat agar dapat mengena ummat yang menjadi jama'ah mereka dengan maksimal.

Menurut Gusnadi (1998: 47-49), efek atau hasil akhir dari suatu komunikasi, yakni, sikap atau tingkah laku orang sesuai atau tidak dengan yang kita inginkan. Efek yang timbul dapat diklasifikasikan menurut kadarnya, yakni :

\section{Dampak Afektif}

Adalah dampak pesan yang disampaikan komunikator yang ditujukan bukan hanya sekedar agar komunikan tahu, tetapi juga untuk meggerakkan hatinya serta untuk menimbulkan 
perasaan tertentu, misalnya perasaan iba, terharu, sedih, gembira, marah dan sebagainya.

\section{Dampak Kognitif}

Adalah dampak yang timbul pada komunikan yang menyebabkan dia menjadi tahu atau mengingat intelektualitasnya. Disini pesan yang disampaikan oleh komunikator adalah berkisar pada upaya mengubah pikiran dari komunikan.

\section{Dampak Behavioral}

Adalah dampak yang timbul pada komunikan dalam bentuk perilaku, tindakan atau kegiatan. Proses komunikasi juga berdampak sosial terhadap masyarakat berupa perubahan perilaku, cara hidup, nilai-nilai sosial, norma-norma sosial dalam masyarakat.

\section{Berdakwah Islamiyah di Daerah Pesisir}

Seorang penceramah akan memiliki ciri khas dalam berdakwah dan bisa dibedakan dari cara pandang para jama'ahnya, entah melalui pilihan kata, struktur kalimat, nada, dan makna yang digunakan. Akan tetapi, terkadang para jama'ah masih kurang memahami gaya bahasa dakwah Islam berdasarkan pilihan kata, struktur kalimat, nada, dan makna tersebut. Oleh karenanya, seorang penceramah haruslah memperhatikan kaidah-kaidah yang baik dalam berdakwah agar tidak menampilkan suasana dakwah yang buruk di hadapan para jama'ah dan harus disesuaikan dengan cara pandang masyarakat pada umumnya.

Berbicara mengenai jama'ah atau ummat Islam yang berada di daerah pesisir, seorang penceramah haruslah memaklumi sterotype mereka, dimana seorang penceramah haruslah pandai dan cerdas mengklasifikasikan materi dan metode dakwahnya berdasarkan jama'ahnya agar dakwah tersebut bisa berjalan efektif dan efisien (matching) sesuai dengan kebutuhan jama'ah itu sendiri. Sejalan dengan materi dan metode dakwah, pemilihan bahasa baik verbal maupun non-verbal tak kalah andilnya dalam terwujudnya tujuan dakwah.

Sebelum masuk kepada pembahasan bagaimana seharusnya seorang penceramah atau pendakwah berdakwah di daerah pesisir, ada baiknya kita pahami terlebih dahulu definisi masyarakat pesisir itu. Menurut Soegiarto (1976), pesisir merupakan daerah pertemuan antara darat dan laut. ke arah darat meliputi bagian daratan, baik kering maupun terendam air, yang masih dipengaruhi sifat-sifat laut seperti pasang surut, angin laut, dan perembesan air asin. Sedangkan ke arah laut meliputi bagian laut yang masih dipengaruhi oleh proses-proses alami yang terjadi di darat seperti sedimentasi 
dan aliran air tawar, maupun yang disebabkan oleh kegiatan manusia di darat seperti penggundulan hutan dan pencemaran.

Selanjutnya, masyarakat pesisir adalah sekumpulan masyarakat yang hidup bersama-sama mendiami wilayah pesisir membentuk dan memiliki kebudayaan yang khas yang terkait dengan ketergantungannya pada pemanfaatan sumber daya pesisir (Satria, 2004). Secara teoritis, masyarakat pesisir didefinisikan sebagai masyarakat yang tinggal dan melakukan aktifitas sosial ekonomi yang terkait dengan sumber daya wilayah pesisir dan lautan. Dengan demikian, secara sempit masyarakat pesisir memiliki ketergantungan yang cukup tinggi dengan potensi dan kondisi sumber daya pesisir dan lautan.

Tak dapat kita pungkiri bahwa dalam proses penyebarannya, Agama Islam sebagian besar melalui daerah pesisir, sehingga dapat diasumsikan bahwa mereka beranak pinak hingga sekarang. Berdasarkan kondisi geografisnya yang berlatar belakang pesisir dan lautan, besar kemungkinan mereka memiliki aktivitas sosial ekonomi yang terkait dengan potensi dan kondisi sumber daya yang ada di dalamnya, selain memperoleh pencerahan rohani dan keagamaan, mereka pun membutuhkan sesuatu yang dapat membuat mereka merasa nyaman dan tersemangati. Walaupun masyarakat pesisir cenderung berkarakter keras dan temperamental sebab kondisi mereka yang bergantung kepada kondisi alam (Mubyarto, 1984:10), tetapi mereka menganggap bahwa pendidikan (baik itu pendidikan keagamaan maupun umum) adalah penawar kegundahan mereka.

Ketika seorang penceramah melakukan dakwah dengan jama'ah masyarakat pesisir, ada beberapa hal yang perlu dipertimbangkan (sejalan dengan teori yang dikemukakan Gorys Keraf, 1981), yakni:

1. Seorang penceramah haruslah mempertimbangkan masa atau waktu ia berdakwah/berceramah. Misalnya, ketika ia berdakwah mengemukakan masalah yang sedang hangat menjadi perbincangan publik. Bahkan lebih baik lagi ketika ia membuat analogi menggunakan background kondisi yang ada di masyarakat pesisir.

2. Medium yang digunakan haruslah sesuai dengan masyarakat pesisir yang menjadi audience atau jama'ahnya. Sebagai contoh, penceramah tersebut menggunakan bahasa yang mudah mereka cerna ataupun menggunakan bahasabahasa selingkun yang familiar di lingkungan mereka.

3. Subyek dalam hal ini adalah materi yang diangkat oleh seorang 
penceramah sebaiknya merupakan materi yang mengena kehidupan mereka sehari-hari sebagai masyarakat pesisir, baik dalam mencari nafkah, maupun dalam kehidupan sosial kemasyarakatan.

4. Pertimbangan tempat/lokasi berdakwah (dalam hal ini daerah pesisir), dimana secara geografis mereka berada di dekat perairan yang mengakibatkan mereka membutuhkan suara yang lebih keras dan ekspresi yang sesuai. Selain itu, mengetahui bahasa yang mereka pergunakan dalam bersosialisasi serta bergaul sehari-hari dan menggunakannya sekali-kali dalam proses berdakwah, merupakan salah satu gaya pemikat bagi mereka, sebab mereka merasa dihargai oleh sang penceramah tersebut.

5. Pertimbangn hadirin/jama'ah merupakan hal yang sama pentingnya dengan pemilihan subyek/materi dakwah dan gaya berbahasa. Ketika subyek dan gaya berbahasa dakwah disesuaikan dengan jama'ah yang hadir, maka pesan dakwah akan lebih mudah terserap. Selain itu, proses dakwah tersebut akan berjalan interaktif, sebab antara penceramah dan jama'ah seolah-oleh tak ada gap atau ruang yang membedakan.

6. Dalam menyampaikan dakwah islamiyah, tujuan seorang penceramah dalam berdakwah haruslah sesuai dengan kondisi kebutuhan jama'ah pesisir. Dimana seorang penceramah haruslah mengetahui apa yang menjadi kebutuhan mereka. Misalnya, mereka membutuhkan asupan materi dakwah mengenai memanfaatkan ciptaan Allah, adab berlaut, hubungan manusia dengan lingkungan, dll. Ketika yang didakwahkan jauh dari hal yang mereka butuhkan, maka tujuan seorang penceramah bisa jadi tidak tercapai.

7. Nada bicara seorang penceramah ketika berhadapan dengan masyarakat pesisir tidak jauh beda dengan pengaturan nada bicara dengan jama'ah lainnya, tetapi harus dipertimbangkan ketika penceramah harus menekankan sesuatu kepada mereka sementara angin bertiup dengan kencangnya. Hal ini mengakibatkan nada suara haruslah dipertegas.

Dari penjelasan di atas dapat disimpulkan bahwa gaya bahasa seorang penceramah dalam berdakwah di masyarakat pesisir tidak terlalu berbeda dengan berceramah di masyarakat lainnya, hanya saja penceramah tersebut haruslah mempertimbangkan situasi geografis, karakter dan sterotype mereka, 
disamping itu penceramah haruslah lebih cerdas dalam membaca situasi dan kondisi masyarakat yang menjadi jama'ah atau audiencenya.

\section{E. Penutup}

Berdakwah merupakan kewajiban setiap muslim dimanapun ia berada. Hal ini ditegaskan dalam al-Quran dan Hadis-Nya. Sebagai khalifah di muka bumi yang dilengkapi dengan akal, kita harus senantiasa mampu membawa pencerahan untuk muslim lainnya. Daerah pesisir sebagai suatu daerah yang jarang terjamah dakwah-dakwah yang bersifat kekinian membutuhkan variasi dakwah yang dapat memancing ketertarikan mereka dengan kesibukan yang lumayan keras dalam mencari nafkah yang tergantung pada kebaikan alam dalam mendengarkan risalah Islam ini.

\section{F. Daftar Pustaka}

Achmadi, Muchsin. 1988. Materi Dasar Pengajaran Komposisi Bahasa Indonesia. Jakarta: Depdikbud.

Amiruddin. 1995. Stilistika, Pengantar Memahami Bahasa dalam Karya Sastra. Semarang: IKIP Semarang Press.

A. Hasmy. 1984. Dustur Dakwah menurut al-Qur'an. Jakarta: Bulan Bintang.

Asmuni Syukir. 1983. Dasar-Dasar Strategi Dakwah Islam. Surabaya: Al-Ikhlas.

Dakir. 1993. Dasar-Dasar Psikologi. Yogyakarta: Pustaka Belajar.
Ernest G. Bormann dan Nancy C. Bormann. 1991. Retorika Suatu Pendekatan Terpadu. Jakarta: Penerbit Erlangga.

Gorys, Keraf. !981. Diksi dan Gaya Bahasa. Flores: Nusa Indah. 2000. Diksi Dan Gaya Bahasa. Jakarta: PT. Gramedia Pustaka Utama.

Haq, Muhammad Zairul. 2010. Muhammad saw. sebagai Guru. Bantul: Kreasi Kencana.

Jhon M. Echols dan Hasan Shadily. 1992. Kamus Inggris Indonesia, Jakarta: Gramedia.

Luxemburg, Jan Van, dkk. 1989. Pengantar Ilmu Sastra. Terj. Dick Hartoko. Jakarta: Gramedia.

Munir, M. 2012. Manajemen Dakwah. Jakarta: Kencana.

Pradop, Rachmat Djoko. 1997. Pengkajian Puisi. Yokyakarta: Gadjah Mada University Press.

Tarigan, Henry Guntur. 1985. Pengajaran Gaya Bahasa. Bandung: Angkasa.

W. Widjaja. 1993. KomunikasiKomunikasi dan Hubungan Masyarakat. Jakarta: Bumi Aksara.

Wasty Soemanto. 1998. Psikologi Pendidikan. Jakarta: Rineka Cipta.

Y. S Gunadi. 1998. Himpunan Istilah Komunikasi. Jakarta: PT. Grasindo. 